Supporting Information for

\title{
Mechanistics of Lithium-Metal Battery Performance by Separator Architecture Design
}

\author{
Wenxiu Wang, Feng Hao, and Partha P. Mukherjee* \\ School of Mechanical Engineering, Purdue University, West Lafayette, IN 47907, USA
}

${ }^{*}$ Corresponding author: pmukherjee@purdue.edu (P.P. Mukherjee). 


\subsection{Both sides of PP are covered with AO}

We add another separator architecture regime that has both sides of PP are covered with AO film (denoted as APA), and compare the cycling performance of the symmetric Li-Li cells with that using previously two different separator architectures (AP and PP), under the current densities of $1 \mathrm{~mA} / \mathrm{cm}^{2}$ and $2 \mathrm{~mA} / \mathrm{cm}^{2}$, with the same cycling capacity of $0.5 \mathrm{mAh} / \mathrm{cm}^{2}$.

Figure S1(a) shows the cycling performance of the symmetric Li-Li cells at a moderately high current density of $1 \mathrm{~mA} / \mathrm{cm}^{2}$ and a cycling capacity of $0.5 \mathrm{mAh} / \mathrm{cm}^{2}(1 \mathrm{~h} /$ cycle). If $0.5 \mathrm{~V}$ is set as the voltage limit, the lifespan: APA cell $(\sim 115 \mathrm{~h})>$ AP cell $(\sim 109 \mathrm{~h})>$ PP cell $(\sim 85 \mathrm{~h})$, and the voltage: AP cell $<$ APA cell $<$ PP cell.

Figure S1(b) shows the cycling performance of the symmetric Li-Li cells at a higher current density of $2 \mathrm{~mA} / \mathrm{cm}^{2}$ and a cycling capacity of $0.5 \mathrm{mAh} / \mathrm{cm}^{2}(0.5 \mathrm{~h} /$ cycle $)$. If $0.5 \mathrm{~V}$ is set as the voltage limit, the lifespan: AP cell $(\sim 44 \mathrm{~h})>$ APA cell $(\sim 40 \mathrm{~h})>$ PP cell $(\sim 38 \mathrm{~h})$, and the voltage: AP cell $<$ PP cell $<$ APA cell.

Compared with AP cell, the cell life of the APA cell has been improved under a moderate current density of $1 \mathrm{~mA} / \mathrm{cm}^{2}$. However, the cell life of the APA cell is less than that of the AP cell under a higher current density of $2 \mathrm{~mA} / \mathrm{cm}^{2}$. The thickness of the PP layer is $25 \mu \mathrm{m}$, and the thickness of the AO layer is $60 \mu \mathrm{m}$. From the cycling profiles in Figure S1, the thicker APA leads to a larger voltage, which could be caused by prolonged ion migration paths due to the increased total thickness of the PP layer and AO layers $(25 \mu \mathrm{m}+2 * 60 \mu \mathrm{m})$. Therefore, a moderate thickness is essential for an ideal separator, especially under high current densities. 

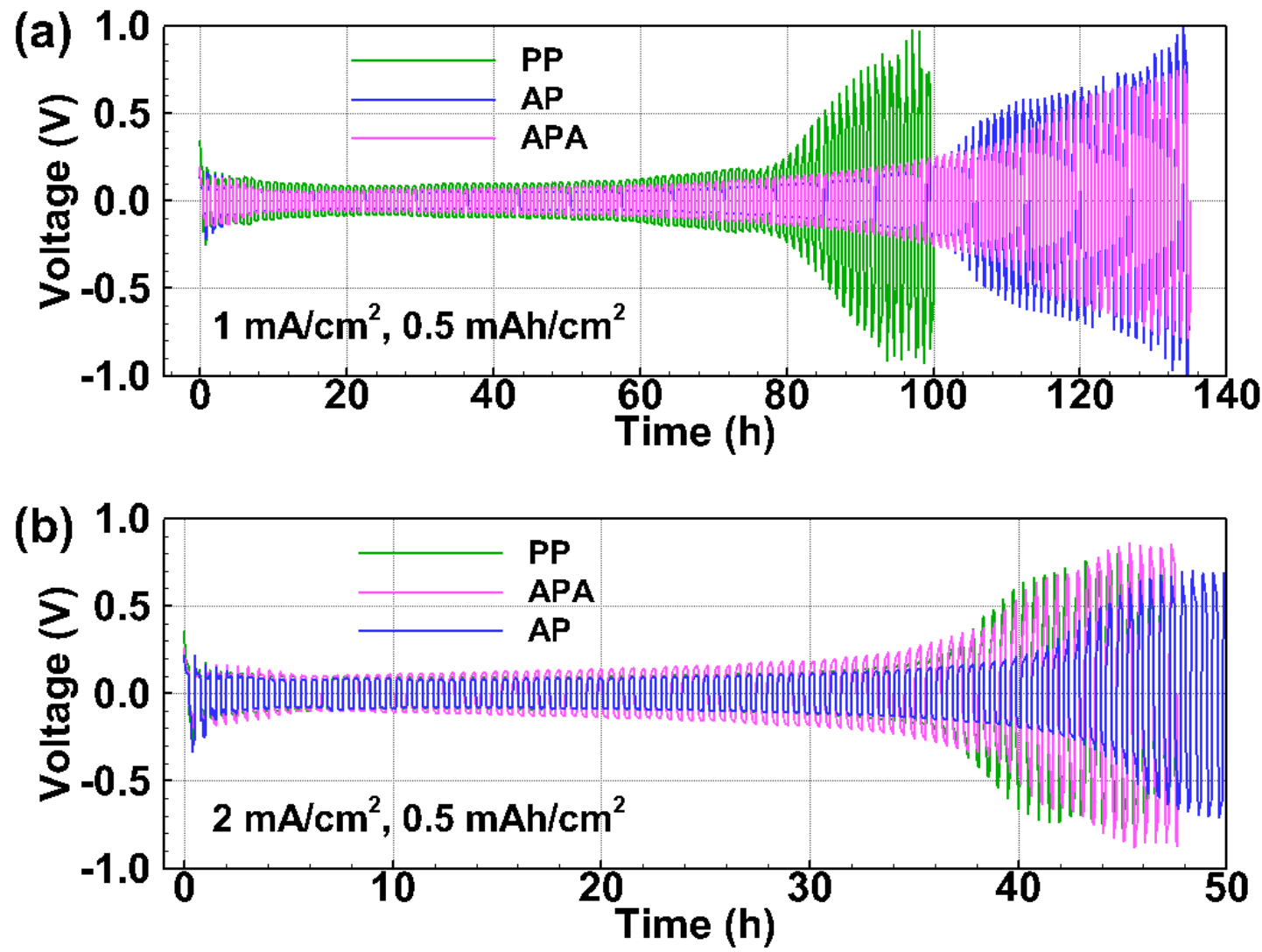

Figure S1. Comparison of the cycling performance of symmetric Li-Li cells using different separators (PP, AP and APA), under the current densities of (a) $1 \mathrm{~mA} / \mathrm{cm}^{2}$ and (b) $2 \mathrm{~mA} / \mathrm{cm}^{2}$ with the same cycling capacity of $0.5 \mathrm{mAh} / \mathrm{cm}^{2}$. 


\subsection{Triple-layer PP separator}

We add another architecture of a triple-layer PP separator $\left(3^{*} 25 \mu \mathrm{m}=75 \mu \mathrm{m}\right)$ (denoted as 3PP), and compare its cycling performance with that of previously designed separator architectures (AP and PP), under the current densities of $1 \mathrm{~mA} / \mathrm{cm}^{2}$ and $2 \mathrm{~mA} / \mathrm{cm}^{2}$, with the same cycling capacity of $0.5 \mathrm{mAh} / \mathrm{cm}^{2}$.

Figure S2(a) shows the cycling performance of the symmetric Li-Li cells at a moderate current density of $1 \mathrm{~mA} / \mathrm{cm}^{2}$ and a cycling capacity of $0.5 \mathrm{mAh} / \mathrm{cm}^{2}(1 \mathrm{~h} /$ cycle). If $0.5 \mathrm{~V}$ is set as the voltage limit, the lifespan: AP cell $(\sim 109 \mathrm{~h})>3$ PP cell $(\sim 93 \mathrm{~h})>$ PP cell $(\sim 85 \mathrm{~h})$, and the voltage: AP cell $<$ PP cell $<3$ PP cell.

Figure S2(b) shows the cycling performance of the symmetric Li-Li cells at a higher current density of $2 \mathrm{~mA} / \mathrm{cm}^{2}$ and a cycling capacity of $0.5 \mathrm{mAh} / \mathrm{cm}^{2}(0.5 \mathrm{~h} /$ cycle $)$. If $0.5 \mathrm{~V}$ is set as the voltage limit, the lifespan: AP cell $(\sim 44 \mathrm{~h})>$ PP cell $(\sim 38 \mathrm{~h})>3 \mathrm{PP}$ cell $(\sim 35 \mathrm{~h})$, and the voltage: AP cell $<$ PP cell $<3 \mathrm{PP}$ cell.

Under a moderate current density of $1 \mathrm{~mA} / \mathrm{cm}^{2}$, the cell life of the 3PP cell has been improved compared with the PP cell, though it is less than that of the AP cell. However, the cell life of the 3PP cell is even less than that of the PP cell under the higher current density of $2 \mathrm{~mA} / \mathrm{cm}^{2}$. The thickness of the PP layer is $25 \mu \mathrm{m}$, and the thickness of the AO layer is $60 \mu \mathrm{m}$. For the AP layer, the total thickness is, $25+60=85 \mu \mathrm{m}$. For the triple-layer PP separator $3 \mathrm{PP}$, the total thickness is, $3^{*} 25 \mu \mathrm{m}=75 \mu \mathrm{m}$. From the cycling profiles in Figure S2, the thicker AP $(\sim 85 \mu \mathrm{m})$ has a longer cycle life and a lower voltage compared to the case of 3PP $(\sim 75 \mu \mathrm{m})$. The AP cells still outperform the 3PP cells, although the ion migration path is relatively longer for the AP cell due to the increased thickness. The results indicate that the improved cycle life obtained from the AP separators is not simply due to the thicker separator possessing high electrolyte retention. 
Instead, high electrolyte retention, high mechanical strength, and precisely ordered separator architecture contribute to the improved performance of the AP cell in the current work.
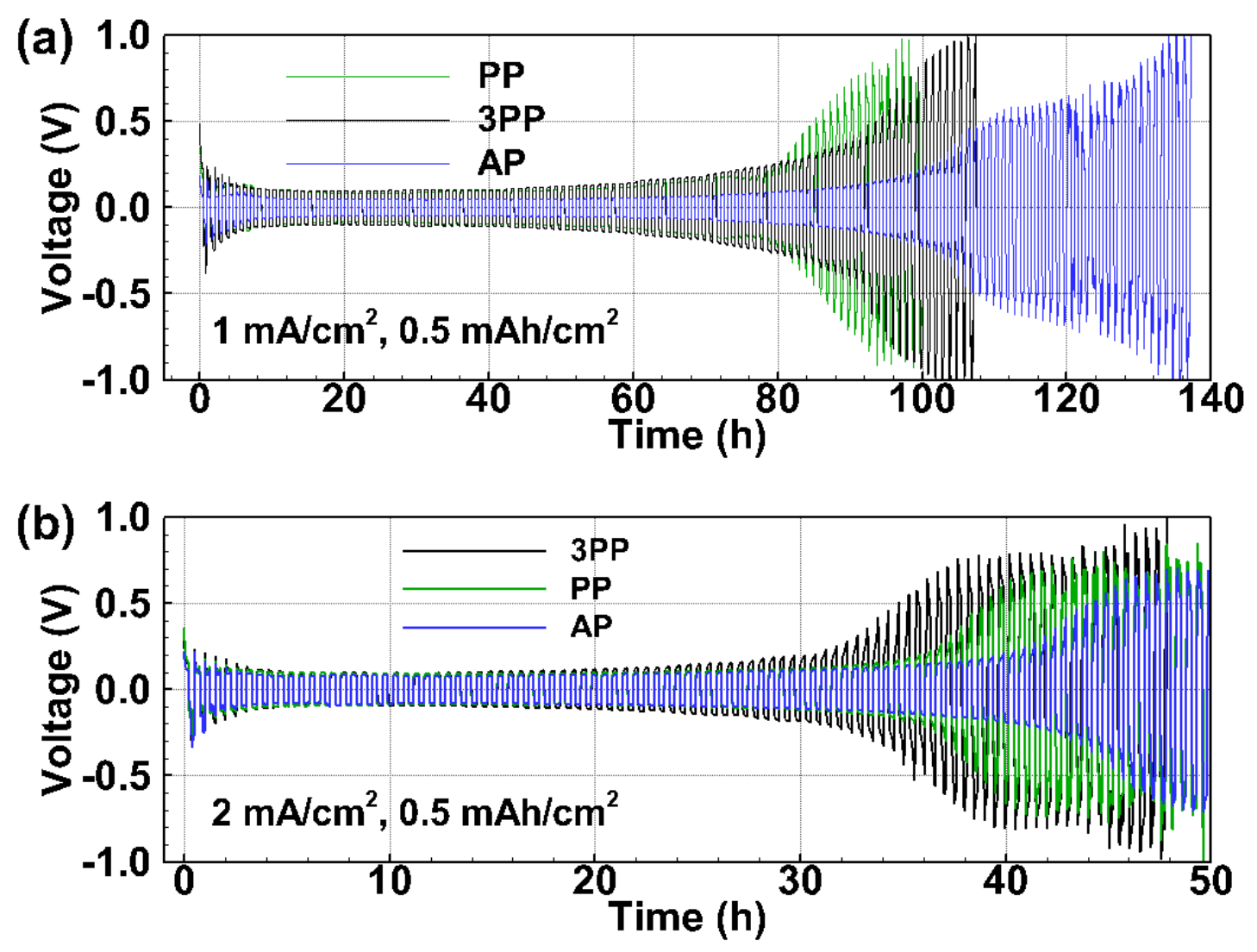

Figure S2. Comparison of the cycling performance of symmetric Li-Li cells using different separators (PP, AP and 3PP), under the current densities of (a) $1 \mathrm{~mA} / \mathrm{cm}^{2}$ and (b) $2 \mathrm{~mA} / \mathrm{cm}^{2}$ with the same cycling capacity of $0.5 \mathrm{mAh} / \mathrm{cm}^{2}$. 


\subsection{Large capacities}

We add more experiments that have larger cycling capacity of $1 \mathrm{mAh} / \mathrm{cm}^{2}$ and $2 \mathrm{mAh} / \mathrm{cm}^{2}$ under the current density of $1 \mathrm{~mA} / \mathrm{cm}^{2}$. We compare the cycling performance of the symmetric LiLi cells with two different separator architectures (AP and PP). From Figures S3(a-d), the larger capacities have slightly shorter cycle life under the same current density of $1 \mathrm{~mA} / \mathrm{cm}^{2}$. The AP cells outperform PP cells under all the capacities from $0.5 \mathrm{mAh} / \mathrm{cm}^{2}$ to $2 \mathrm{mAh} / \mathrm{cm}^{2}$.

(a) Cycling capacity of $0.5 \mathrm{mAh} / \mathrm{cm}^{2}$ :

if $0.5 \mathrm{~V}$ is set as the voltage limit, the lifespan: AP_200 $\mathrm{nm}(\sim 109 \mathrm{~h})>\mathrm{PP}(\sim 85 \mathrm{~h})$.

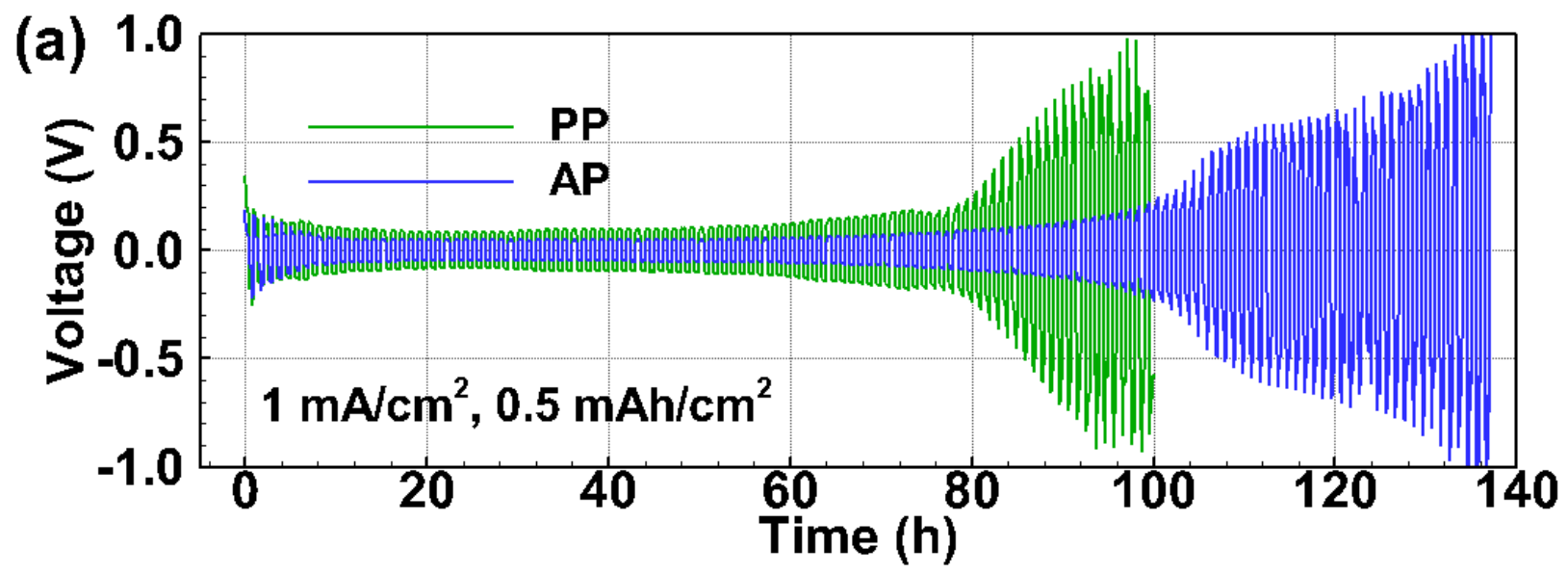

(b) Cycling capacity of $1 \mathrm{mAh} / \mathrm{cm}^{2}$ :

if $0.5 \mathrm{~V}$ is set as the voltage limit, the lifespan: AP_200 $\mathrm{nm}(\sim 105 \mathrm{~h})>\mathrm{PP}(\sim 83 \mathrm{~h})$. 


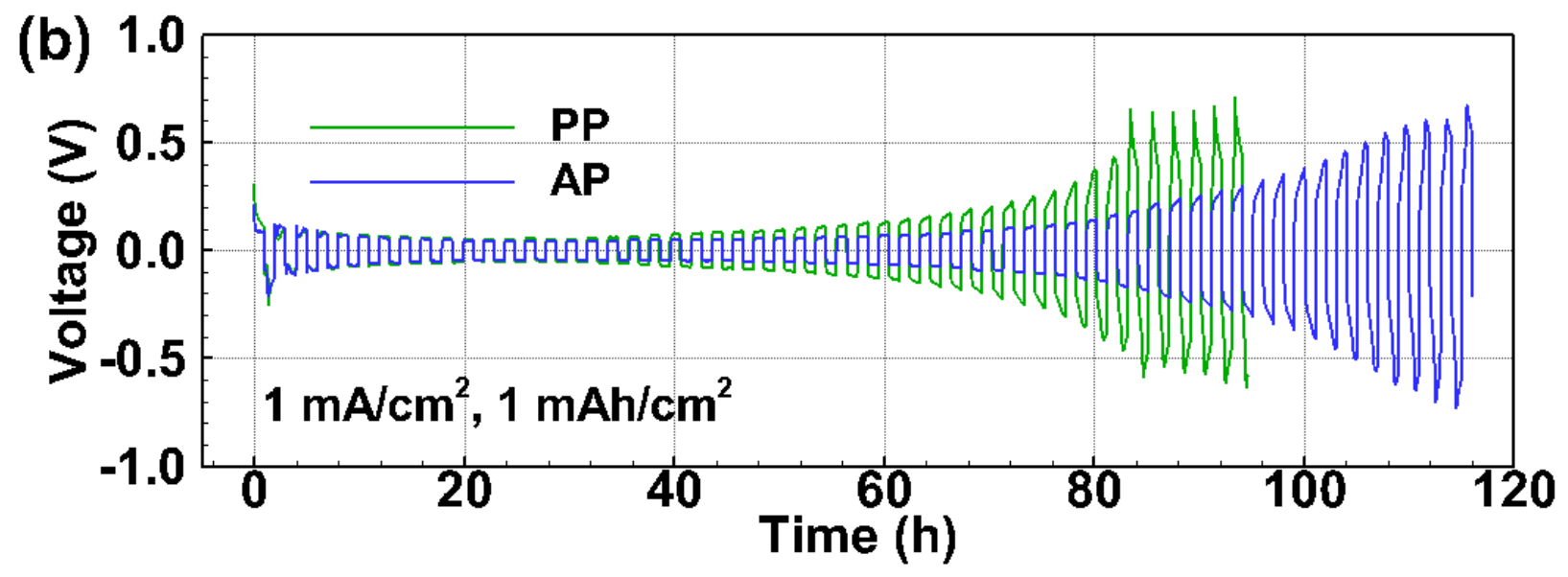

(c) Cycling capacity of $2 \mathrm{mAh} / \mathrm{cm}^{2}$ :

if $0.5 \mathrm{~V}$ is set as the voltage limit, the lifespan: AP_200 nm $(\sim 102 \mathrm{~h})>\mathrm{PP}(\sim 81 \mathrm{~h})$.

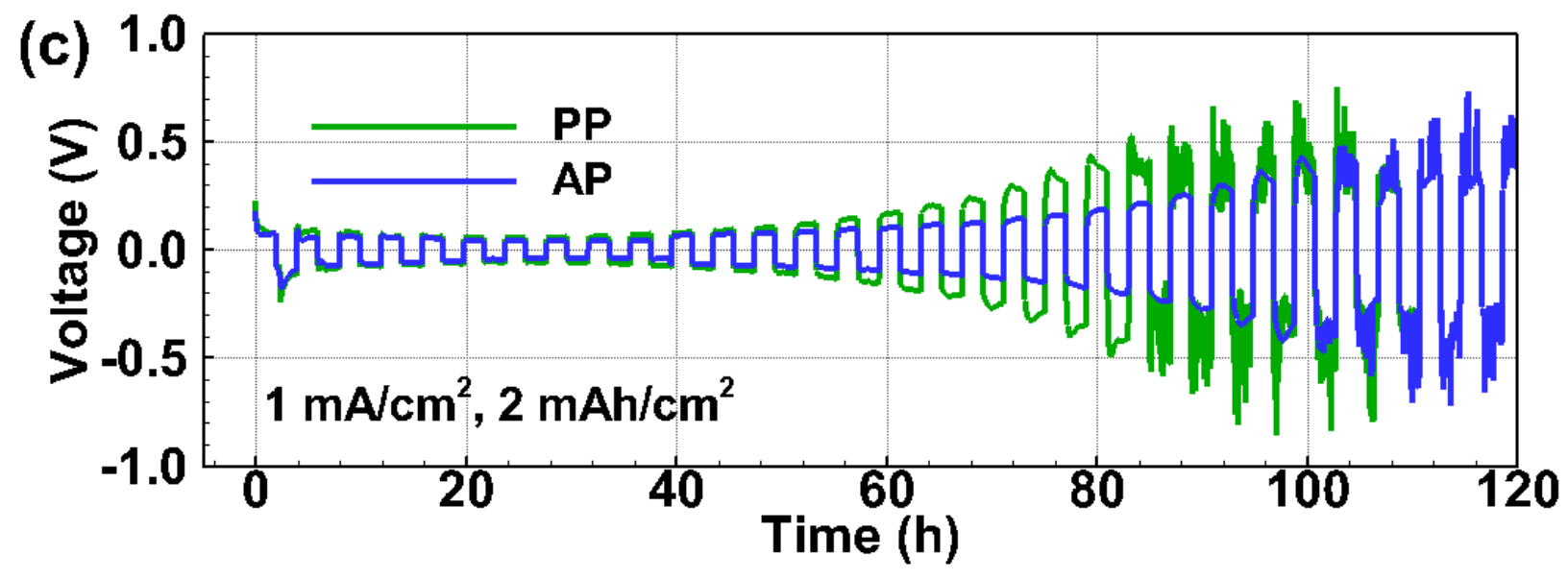

(d) $2 \mathrm{mAh} / \mathrm{cm}^{2}$

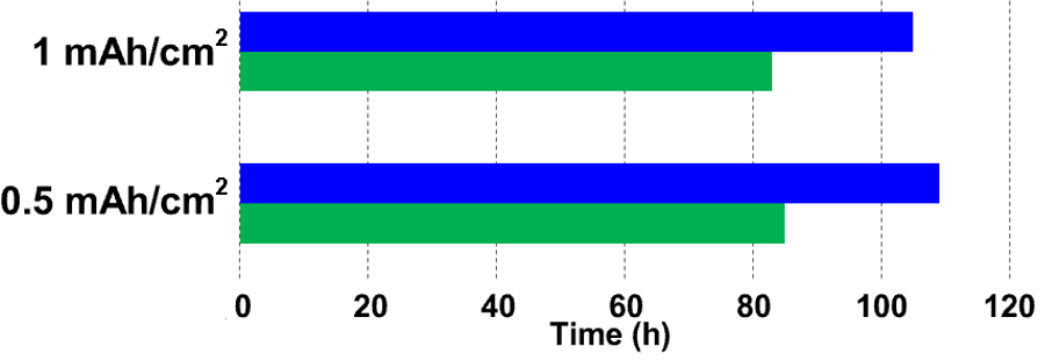


Figure S3. Comparison of the cycling performance of symmetric Li-Li cells using different separators (PP and AP), under the current density of $1 \mathrm{~mA} / \mathrm{cm}^{2}$ with the cycling capacities of (a) $0.5 \mathrm{mAh} / \mathrm{cm}^{2}$, (b) $1 \mathrm{mAh} / \mathrm{cm}^{2}$, (c) $2 \mathrm{mAh} / \mathrm{cm}^{2}$. (d) Summary of the cell life under different cycling capacities. 


\subsection{XPS spectra}

The chemical compositions of the SEI layer on the Li metal surface are investigated by x-ray photoelectric spectroscopy (XPS). Figures S4(a-c) show the C 1s, O 1s and F

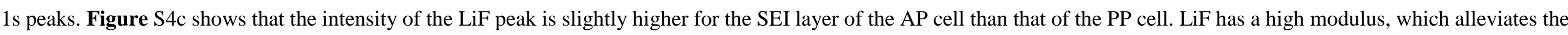
brittle fracture of SEI. LiF also has a high surface energy and surface mobility, which reduces the activation energy barrier to migrate Li ions, and both properties are desirable in suppressing dendrite growth on Li metal anodes ${ }^{1}$. The intensity of the organic $\mathrm{C}=\mathrm{O}$ peak in Figure $\mathrm{S} 4 \mathrm{~b}$ is slightly higher for the SEI layer of the AP cell than that of the PP cell,

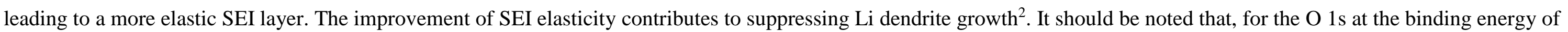
531.5 532 eV, the peak of the metal carbonates $\left(\mathrm{Li}_{2} \mathrm{CO}_{3}\right)$ coincides with the organic $\mathrm{C}=\mathrm{O}$ peak. For the pristine $\mathrm{SEI}$ on $\mathrm{Li}$ surface, the peak should be $\mathrm{Li}{ }_{2} \mathrm{CO}$. For the $\mathrm{Li}$ metal after cycling, the peak should be organic $\mathrm{C}=\mathrm{O}$ in $\mathrm{ROCO}_{2} \mathrm{Li}$.

(a)

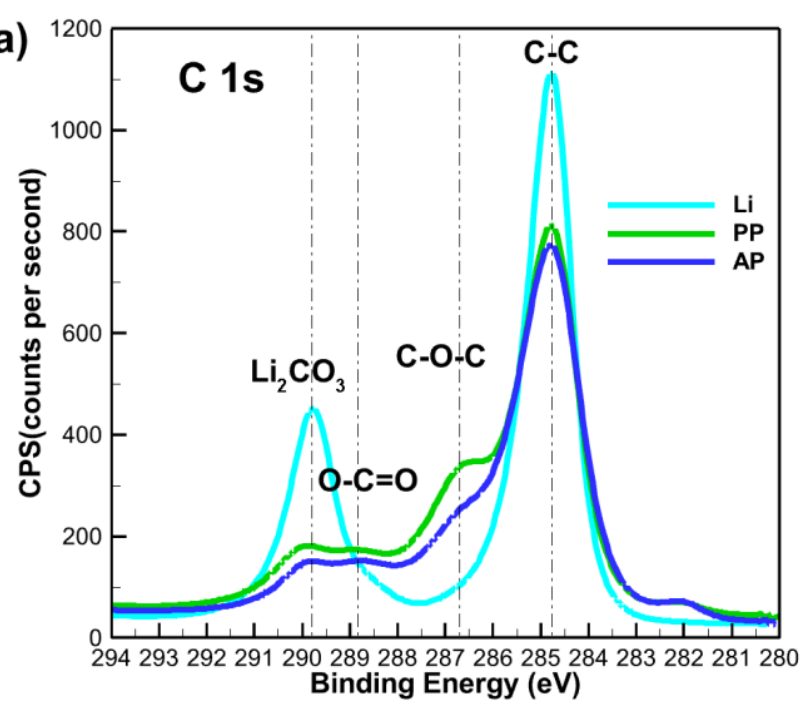

(b)

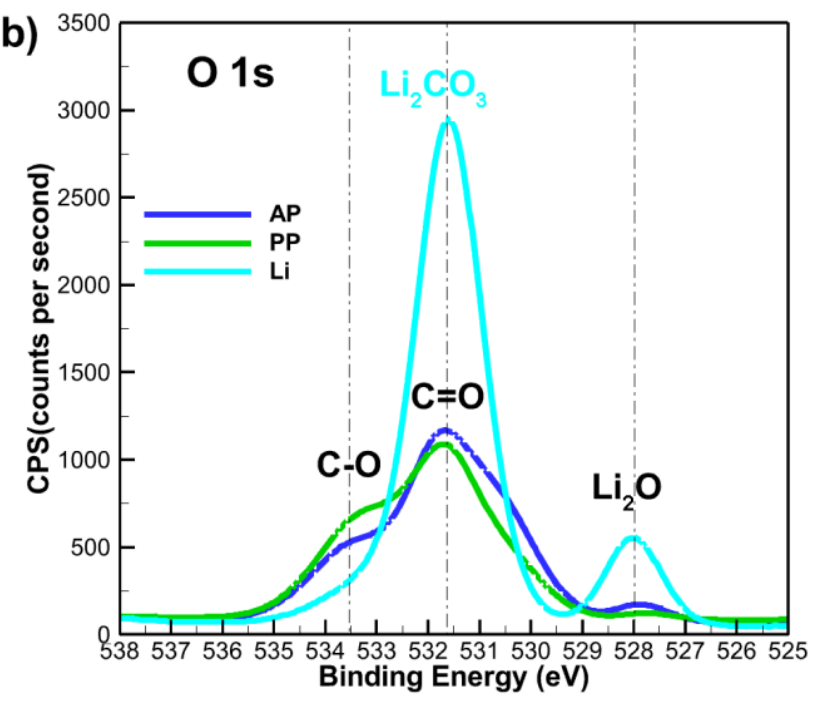

(c)

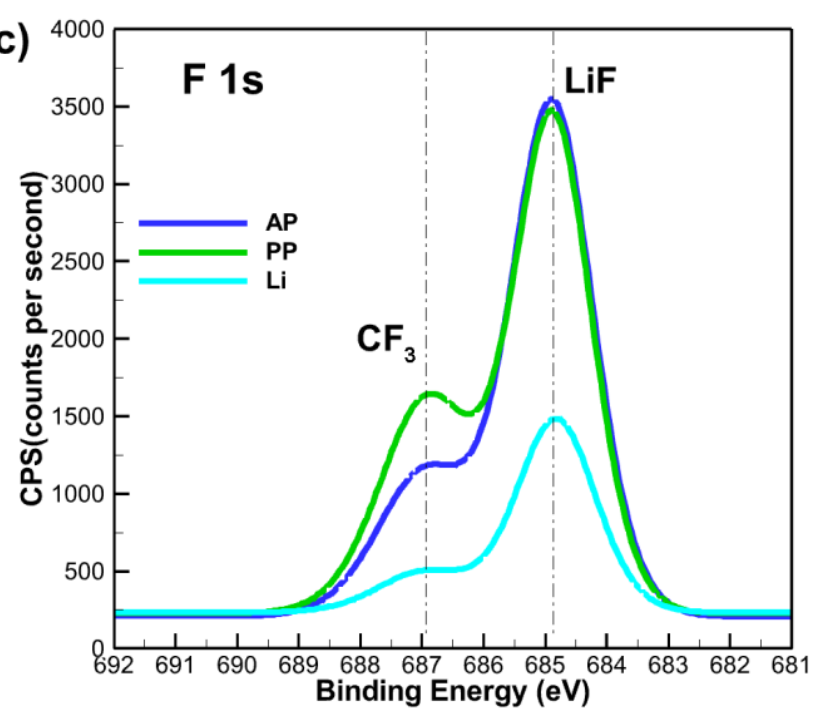

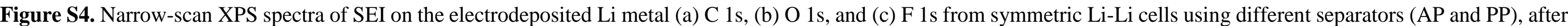
100 cycles with the current density of $1 \mathrm{~mA} / \mathrm{cm}^{2}$ and cycling capacity of $0.5 \mathrm{mAh} / \mathrm{cm}^{2}$. The spectra marked by "Li" represent the pristine SEI on Li surface before cycling. 


\section{REFERENCES}

(1) Zhao, C. Z.; Chen, P. Y.; Zhang, R.; Chen, X.; Li, B. Q.; Zhang, X. Q.; Cheng, X. B.; Zhang, Q. An ion redistributor for dendritefree lithium metal anodes. Science Advances 2018, 4 (11), eaat3446.

(2) Yu, L.; Chen, S. R.; Lee, H.; Zhang, L. C.; Engelhard, M. H.; Li, Q. Y.; Jiao, S. H.; Liu, J.; Xu, W.; Zhang, J. G. A Localized HighConcentration Electrolyte with Optimized Solvents and Lithium Difluoro(oxalate)borate Additive for Stable Lithium Metal Batteries. Acs Energy Letters 2018, 3 (9), 2059-2067. 